\title{
Hallmarks of gastrointestinal neuroendocrine tumours: implications for treatment
}

\author{
Annemiek Walenkamp, Guillermo Crespo ${ }^{1}$, Felipe Fierro Maya ${ }^{2}$, Reidar Fossmark ${ }^{3}$, \\ Peter Igaz ${ }^{4}$, Anja Rinke ${ }^{5}$, Gianluca Tamagno ${ }^{6}$, Giovanni Vitale ${ }^{7,8}$, Kjell Öberg ${ }^{9}$ and \\ Tim Meyer ${ }^{10}$ \\ Department of Medical Oncology, University Medical Centre Groningen, University of Groningen, Hanzeplein 1, \\ 9713 GZ Groningen, The Netherlands \\ 'Department of Medical Oncology, Hospital Universitario de Burgos, Avenida Islas Baleares 3, 09006 Burgos, Spain \\ ${ }^{2}$ Department of Endocrine Oncology, National Cancer Institute, Bogotá, Colombia \\ ${ }^{3}$ Department of Cancer Research and Molecular Medicine, Norwegian University of Science and Technology, \\ 7491 Trondheim, Norway \\ ${ }^{4}$ 2nd Department of Medicine, Semmelweis University, 46, Szentkiralyi Street, H-1088 Budapest, Hungary \\ ${ }^{5}$ Department of Gastroenterology, University Hospital Marburg, Baldinger Strasse, Marburg D-35043, Germany \\ ${ }^{6}$ Department of General Internal Medicine, St Columcille's Hospital, Loughlinstown - Co., Dublin, Ireland \\ ${ }^{7}$ Department of Clinical Sciences and Community Health (DISCCO), University of Milan, Milan, Italy \\ ${ }^{8}$ Laboratory of Endocrine and Metabolic Research, Istituto Auxologico Italiano IRCCS, Via Zucchi 18, \\ Cusano Milanino (MI) 20095, Italy \\ ${ }^{9}$ Department of Endocrine Oncology, University Hospital, Uppsala, Sweden \\ ${ }^{10}$ UCL Cancer Institute, UCL, Huntley Street, London WC1E 6BT, UK
}

Correspondence should be addressed to A Walenkamp

Email

a.walenkamp@umcg.nl

\begin{abstract}
In the past few years, there have been advances in the treatment of neuroendocrine tumours (NETs) and improvements in our understanding of NET biology. However, the benefits to patients have been relatively modest and much remains yet to be done. The 'Hallmarks of Cancer', as defined by Hanahan and Weinberg, provide a conceptual framework for understanding the aberrations that underlie tumourigenesis and to help identify potential targets for therapy. In this study, our objective is to review the major molecular characteristics of NETs, based on the recently modified 'Hallmarks of Cancer', and highlight areas that require further research.
\end{abstract}
Key Words
- cancer
- neuroendocrine tumours
- treatment
tumourigenesis

Endocrine-Related Cancer (2014) 21, R445-R460

\section{Introduction}

Neuroendocrine tumours (NETs) are diverse in their site of origin and clinical behaviour, ranging from highly aggressive small cell cancers of the lung to indolent, lowgrade tumours of the small bowel (Yao et al. 2008a). Symptoms arise from both the tumour burden and the secretion of bioactive hormones by the so-called 'functional tumours'. High-grade tumours are often treated with chemotherapy, while for low-grade tumours, the focus may be on alleviating the consequences of hormone secretion with somatostatin analogues (SSAs; Ramage et al. 2012). The recent approval of sunitinib (Raymond et al. 2011) and everolimus (Yao et al. 2011) for the treatment of pancreatic NETs provides evidence for the importance of angiogenesis and the mTOR pathway in the pathogenesis of NETs, but there remains a significant unmet need to improve outcomes in this disease. Recently, Hananhan and Weinberg have published an updated version of their original 'Hallmarks of Cancer', in

Published by Bioscientifica Ltd 
which they provide a conceptual framework for understanding the mechanisms that underlie tumourigenesis. In their initial review, they defined six 'hallmarks': i) sustaining proliferative signalling, ii) evading growth suppressors, iii) activating invasion and metastasis, iv) enabling replicative immortality, v) inducing angiogenesis and vi) resisting cell death (Hanahan \& Weinberg 2000). To these have been added four further hallmarks: avoiding immune destruction, dysregulating cellular energetics, tumour promoting inflammation, and genome instability and mutation (Hanahan \& Weinberg 2011). We have sought to apply this framework to the current understanding of NET biology in order to identify opportunities for research that may improve our understanding and inform therapeutic developments (see Figs 1 and 2). We have also reviewed ongoing clinical trials based on these concepts (see Supplementary Table 1, see section on supplementary data given at the end of this article).

\section{Sustaining proliferative signalling}

G protein-coupled receptors (GPCRs) have been extensively studied in NETs, and stimulation or inhibition of such receptors appears to contribute to sustained tumour growth. GPCRs are a broad and very heterogeneous family of seven trans-membrane domain receptors linked to a G protein. A number of GPCRs have been found to be

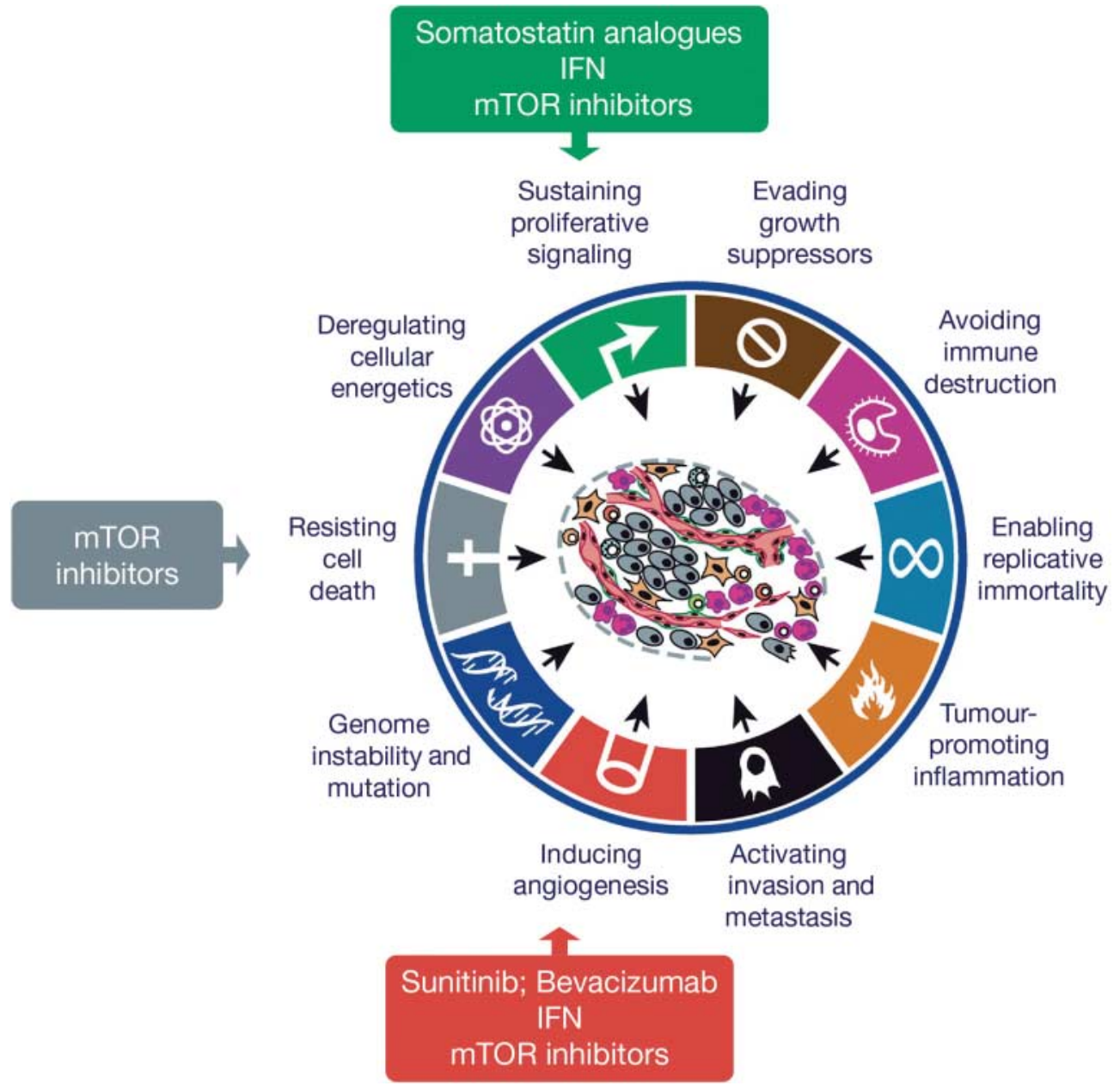

Figure 1

Hanahan and Weinberg's next generation hallmarks of cancer. As shown, some molecular targets have led to the development of targeted drug treatments for patients with GEP-NET, but there remains a lack of specific investigational drugs for most of the hallmarks of cancer in neuroendocrine tumours. These are potential research opportunities that may eventually improve the therapeutic armamentarium in GEP-NET patients. mTOR, mammalian target of rapamycin; IFN, interferon. Reproduced from Cell, 144, Hanahan D \& Weinberg RA, Hallmarks of cancer: the next generation, pages 646-674, Copyright (2011), with permission from Elsevier. 


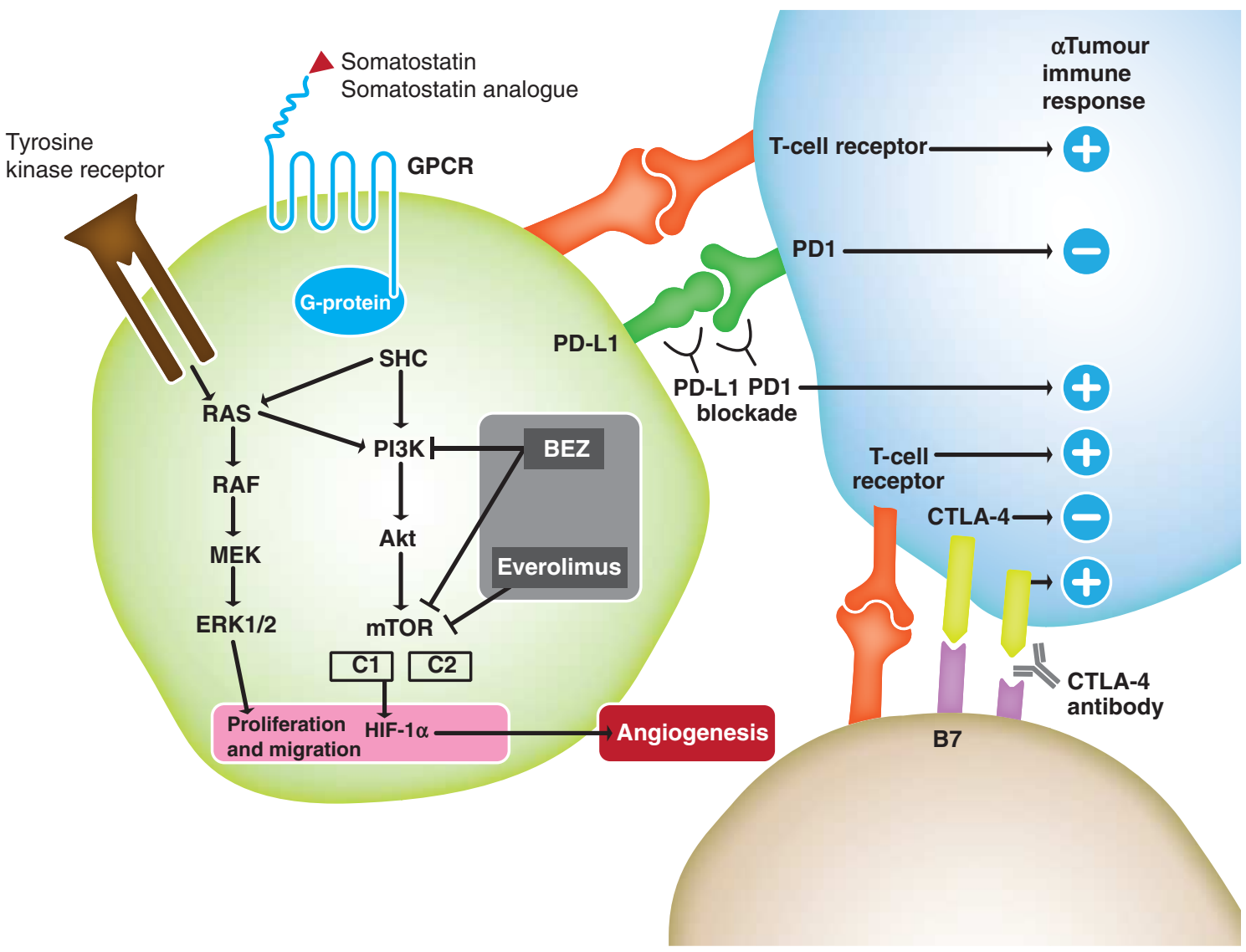

Figure 2

Hallmarks of neuroendocrine tumours: mechanisms of tumourigenesis and targets for therapy. BEZ, BEZ235 or NVP-BEZ235, an imidazoquinoline derivative; CTLA4, cytotoxic T-lymphocyte antigen 4; ERK1/2, extracellular signal-regulated protein kinase $1 / 2 ; \mathrm{GPCR}$, G-protein coupled receptor; HIF $1 \alpha$, hypoxia-inducible factor- $1 \alpha$; MEK, mitogen-activated protein kinase

excellent targets for gastrointestinal NET (GEP-NET) diagnosis and therapy (Pavel 2013).

\section{Somatostatin receptors}

The most widely studied are the somatostatin receptors (SSTRs), which bind somatostatin and its therapeutic analogues. Five SSTR subtypes (SST1-SST5) have been identified. Two spliced variants of SSTR2 (SSTR2A and SSTR2B) have been found, with SSTR2A having the highest expression and the greatest relevance from a biological and clinical perspective. Somatostatin and its synthetic analogues (octreotide and lanreotide) act through the five specific SSTRs found on the cell membranes of various tumours, including GEP-NET (Diakatou et al. 2011). The first step of the signalling cascade following agonist stimulation is the internalisation of the SSTR (Scott et al. 2002). Functional coupling of receptors is part of the kinase; mTOR, mammalian target of rapamycin; $\mathrm{C} 1, \mathrm{mTOR}$ complex 1; C2, mTOR complex 2; PD1, programmed cell death protein 1; PD-L1, programmed death-ligand 1; PI3K, phosphatidylinositol 3-kinase; SHC, Src homology 2 domain containing.

signalling process, with dimerisation occurring between different SSTR subtypes (homodimerisation) or between SSTRs and other GPCRs (heterodimerisation) (DuranPrado et al. 2008). SSAs preferentially target the SSTR2, which is highly expressed in GEP-NETs. However, some tumours are resistant to SSAs and it is not known whether the defect lies in the activation of the SSTR or downstream signalling events. Phosphorylated SSTR2s are present in most GEP-NETs from patients treated with octreotide, but their sub-cellular distribution varies markedly (Waser et al. 2012a). The activation of SSTRs, particularly SSTR2 and SSTR5, can block the secretion of biologically active peptides from tumour cells (Cakir et al. 2010a,b, Gatto \& Hofland 2011) and may lead to the inhibition of cell growth and the induction of apoptosis (Strosberg \& Kvols 2010).

The internalisation of activated SSTRs together with their bound ligands allows cold or radiolabelled

Published by Bioscientifica Ltd 
somatostatin/SSAs to be administered (Cescato et al. 2006), with obvious implications for the radiological diagnosis and treatment of GEP-NETs. Hence, SSAs are the standard treatments for GEP-NETs, in particular those associated with carcinoid syndrome (ENETS 2008, Gatto \& Hofland 2011). Evidence obtained recently indicates that SSAs have an anti-proliferative effect on GEP-NETs via a number of pathways (Strosberg \& Kvols 2010). Both octreotide and lanreotide, which have slightly different binding affinities to SSTR2 and SSTR5 (the most clinically relevant SSTR subtypes), can exert an in vivo anti-proliferative role. Results from a phase III randomised placebocontrolled trial have indicated that long-acting octreotide can significantly prolong the time to tumour progression in patients with a metastatic midgut NET (Rinke et al. 2009) and this has recently been confirmed for intestinal and pancreatic NET patients using lanreotide autogel in the CLARINET study (Caplin et al. 2014). New SSAs such as pasireotide, which binds four of the five SSTR subtypes with a high affinity, have been developed to optimise the activation of SSTRs expressed at GEP-NET cell membranes. In a phase II study, pasireotide appeared to be reasonably well tolerated and effective in controlling carcinoid syndrome in patients with an octreotide-refractory or resistant advanced tumour (Kvols et al. 2012). However, pasireotide does not appear to be superior to the other commercially available SSAs in controlling the symptoms of carcinoid syndrome (Wolin et al. 2013).

The functional interaction between SSTR subtypes or with other GPCRs, such as the dopamine receptors, can exert a functional effect on the signalling cascade and the strength of the response to the agonist. As SSTRs and dopamine D2 receptors can be co-expressed in GEP-NET cells, it has been proposed that some interaction between the complex formed by the activated receptor and the $\beta$-arrestin of the two receptor families could affect the downstream signalling (Gatto \& Hofland 2011).

\section{Other GPCRs}

Dopamine, a well-characterised neurotransmitter, acts through five dopamine receptors (D1-D5) that are expressed in endocrine tumours (Diakatou et al. 2011). The D2 receptor is the most relevant from a clinical perspective. Using RT-PCR, DRD2 mRNA has been found in all samples of a series of 35 GEP-NETs, although the expression level was generally lower than that in other NETs (O'Toole et al. 2006). The presence of D2 receptors has also been evaluated by immunohistochemistry in well-differentiated NETs originating from different sites.
Receptor expression was found in $85 \%$ of the examined tumours, with particularly high expression observed in pancreatic and duodenal NETs (Grossrubatscher et al. 2008). Targeting the D2 receptor might be an effective mechanism for suppressing NET cell hormone secretion (Gatto \& Hofland 2011). As the activation of these receptors induces phosphodiesterase activity and decreases intracellular cAMP concentration, the consequent inhibition of MAPK signalling might inhibit cell proliferation. Interestingly, an unfavourable clinical outcome has been observed more frequently among GEP-NET patients with low D2 immunoreactivity, although no significant correlation between D2 receptor expression and Ki-67 expression was reported (Grossrubatscher et al. 2008). Thus, the clinical utility of targeting the dopamine receptor in GEP-NETs remains unclear.

The GLP1 receptor has been shown to be greatly overexpressed in NETs, particularly in insulinomas, hence it may represent a novel molecular target for in vivo scintigraphy and targeted radiotherapy. For GLP1 receptor scintigraphy, a low background signal can be expected due to low receptor expression in normal tissues surrounding the tumours (Korner et al. 2007). GLP1 receptor imaging is an innovative, non-invasive, diagnostic approach that successfully localises small insulinomas pre- and intraoperatively (Christ et al. 2009). As opposed to benign insulinomas, malignant insulinomas often lack GLP1 receptors, but frequently express SSTR2s which can be targeted (Wild et al. 2011).

Glucose-dependent insulinotropic polypeptide (GIP) receptors are expressed in the majority of pancreatic, small bowel and bronchial NETs. Receptor binding and mRNA analysis by PCR reveal GIP receptors in many GEP-NETs (Waser et al. 2012b). Indeed, most SSTR-negative NETs and GLP1-receptor-negative malignant insulinomas are GIP-receptor-positive. As most epithelial and stromal gastrointestinal tumours and lung adenocarcinomas are GIP-receptor-negative, the specificity of this receptor could aid GEP-NET targeting (Waser et al. 2012b).

The secretin receptor is also expressed in some NET cell types. This receptor mediates the effects of the gastrointestinal hormone, secretin, on digestion and water homoeostasis via the phosphatidylinositol 3 kinase (PI3K)/serine-threonine protein kinase pathway. In vitro, tumour cells with high secretin receptor expression respond well to PI3K inhibitors, depending on the quantitative receptor expression, and hence this may represent a new pathway to explore in some GEP-NET types (Lee et al. 2012).

Published by Bioscientifica Ltd 
It is well known that serotonin (5-HT), an amine secreted by many NETs, is a strong inducer of fibrosis, although the mechanisms involved in fibrosis and proliferation within tumours are not fully determined (Svejda et al. 2010). The fibrotic process often has an influence on the clinical outcome for GEP-NET patients in terms of development and management of mechanical symptoms. Targeting the 5-HT receptors might allow new antiproliferative and anti-fibrotic strategies for small bowel NETs by inhibiting the activity of fibroblasts and NET cells in the tumour microenvironment (Svejda et al. 2010).

The cause of neuroendocrine hyperplasia as found in the ileum (Sherman et al. 1979, Moyana \& Satkunam 1992) and pancreas (Anlauf et al. 2007) is in most cases not known. However, in the stomach (Solcia et al. 1988), the process is partially understood: hypergastrinaemia stimulates continuous proliferative signalling in enterochromaffin-like cells. Results of research on both model systems and patients have indicated the gastrin/CCK2 receptor to be a potential target for future anti-tumour therapy. The CCK2 receptor is expressed in cancers, where it contributes to tumour progression and is over-expressed in a sub-set of tumours, allowing for its use in tumour targeting with a radiolabelled ligand (Froberg et al. 2009, Sanchez et al. 2012). Antagonising CCK2 receptors inhibits gastrin-mediated enterochromaffin-like cell secretion and proliferation, thus inhibiting in vivo tumour development in rodents (Martinsen et al. 2003) as well as in patients with gastric carcinoids (Fossmark et al. 2012).

A newly discovered GPCR is the olfactory receptor $51 \mathrm{E} 1$ which is significantly expressed in different types of NETs (Cui et al. 2013, Giandomenico et al. 2013).

\section{Evading growth suppression}

An important characteristic of cancer cells is their ability to circumvent cellular growth suppression programmes, most of which are dependent on the activity of tumour suppressor genes.

Several tumour suppressor genes are involved in the pathogenesis of GEP-NETs through evasion of growth suppression. Germline-inactivating mutations of the tumour suppressor gene MEN1 are responsible for the majority of familial NETs (Capurso et al. 2006) and somatic mutations of this gene are present in approximately onethird of sporadic foregut NETs (Rindi \& Bordi 2005). PNETs also occur in von Hippel-Lindau (VHL) disease, which is caused by a mutation in the VHL tumour suppressor gene (Capurso et al. 2006).
Neurofibromatosis type 1 (NF1) and tuberous sclerosis (TS) are both inherited syndromes that can rarely develop PNETs. NF1 and TS are caused by inactivating mutations of the tumour suppressor genes NF1 (17q11.2) and TSC1 (9q34) plus TSC2 (16p13.3) respectively. All these genes code for proteins involved in the negative regulation of the PI3K-AKT-mTOR pathway - a key pathway in the control of cell survival and proliferation (Rindi \& Bordi 2005, Capurso et al. 2006). Altered upstream regulators of mTOR (phosphatase and tensin homologue (PTEN) and TSC2) have also been found in sporadic PNETs (Krausch et al. 2011, Cingarlini et al. 2012).

The retinoblastoma tumour suppressor pathway is inactivated in the majority of PNETs (Tang et al. 2012). One of the mechanisms by which the retinoblastoma pathway inactivation occurs is through over-expression of cyclindependent kinases CDK4 or CDK6. These results provide a strong rationale for the use of inhibitors of CDK4/CDK6 as a potential therapy in PNETs (Tang et al. 2012).

The dysfunction of the p53 pathway is another important mechanism contributing to the initiation and progression of PNETs (Hu et al. 2010, Yachida et al. 2012). This gene plays a crucial role in the control of apoptosis, the cell cycle, genomic stability and inhibition of angiogenesis. Although p53 (TP53) mutations are rare in NETs, the p53 pathway is commonly altered in PNETs through aberrant activation of its negative regulators (MDM2, MDM4 and WIP1) (Hu et al. 2010). Reactivation of p53 through inhibition of these negative regulators is a potential therapeutic strategy for PNETs (Lehmann \& Pietenpol 2012). Somatic mutations targeting the cell cycle regulator gene $C D K N 1 B$ have recently been detected in $8 \%$ of small intestine NETs (Francis et al. 2013).

The down-regulation of other tumour suppressor genes (RASSF1A, CDKN2A, HIC1 and MGMT) by promoter hypermethylation has been reported to be an important event in NET development (Chan et al. 2003, House et al. 2003, Liu et al. 2005, Zhang et al. 2006, Arnold et al. 2007), indicating a potential use of epigenetic therapy in NETs (Rahman et al. 2010).

\section{Avoiding immune destruction}

Research in cancer immunotherapy is partially based on the concept that cancer cells express antigens that elicit $\mathrm{T}$ cell-mediated responses. Patients have been vaccinated against different tumour antigens in attempts to direct patients' own immune systems to attack cancer. However, successful immune system responses against tumours are frequently hindered by the tumour microenvironment,

Published by Bioscientifica Ltd. 
preventing the immune system from eradicating malignant cells (Hanahan \& Weinberg 2011).

In the last decade, development of immunecompetent genetically modified mice has allowed the role of the immune system to be studied, and thereby the elucidation of the complex mechanisms that drive this immune escape (Abe \& Macian 2013). NET cells may escape the immune response by several mechanisms. Tumour-associated antigens (TAAs), along with cytokines from NET cells, dendritic cells (DCs) and tumour-associated macrophages, recruit/induce regulatory $\mathrm{T}$ cells (Tregs), which inhibit the anti-tumour immune response (Ameri \& Ferone 2012). Altered expression of HLA class I molecules has been demonstrated in ten out of 11 pancreatic NETs, loss of $\beta 2$-microglobulin being the most frequent alteration (Ryschich et al. 2003). Immunohistochemical analysis of four patients with lung NET revealed the complete absence of cells expressing DC markers CD1a and CD83, and induction of apoptosis in DCs is a key mechanism by which tumours escape immune recognition and elimination (Katsenelson et al. 2001).

Tregs are crucial for maintaining peripheral tolerance against self-antigens but have also been demonstrated to hinder successful immunotherapy (Zou 2006). In an exploratory study of 68 patients with GE-NETs, increased frequencies of circulating Tregs were demonstrated and, compared with those of healthy donors, a decreased proliferative capacity of $\mathrm{T}$ cells and reduced levels of Th1-promoting cytokines were observed (Vikman et al. 2009). This means that therapeutic strategies are needed to overcome tumour-induced immune suppression. This need has led to the successful development of antibodies directed against cytotoxic T-lymphocyte-associated antigen 4 (CTLA4), programmed cell death protein 1 (PD1) and its ligand (PDL1) (Brahmer et al. 2012, Topalian et al. 2012). The use of Ipilimumab, a fully human MAB that blocks CTLA4 and promotes anti-tumour immunity, has resulted in improved survival in patients with metastatic melanoma (Hodi et al. 2010), but there are no studies reported on NETs.

\section{Enabling replicative immortality}

Telomerase could be an appropriate molecular target for cancer treatment as $90 \%$ of human cancers show telomerase activity (Orlando \& Gelmini 2001), and reconstruction of longer telomeres as a result of telomerase activity could contribute to the unlimited replicative capacity of cancer cells. Telomerase activity can be inhibited in several ways including small-molecule inhibitors, antisense oligonucleotides, immunotherapies and gene therapies (Ruden \& Puri 2013). Some new therapies targeting telomerase activity have entered phase I and II clinical trials, for indications other than GEP-NETs.

Telomerase activity has been suggested as a marker of malignancy in NETs. In patients with pulmonary NETs, telomerase activity was normal in typical carcinoids but elevated in atypical carcinoids, large-cell neuroendocrine cancer and small-cell lung cancer (Gomez-Roman et al. 2000, Zaffaroni et al. 2005, Nishio et al. 2007). Data on telomerase activity in GEP-NET patients are very limited: results from one study in patients with pancreatic NETs (including nine insulinoma patients) indicated that telomerase activity could be a tool for determining the malignant potential of these tumours (Lam et al. 2000), whereas results of another study in a heterogeneous population did not reveal a clear association between telomerase activity and malignancy (Bockhorn et al. 2000).

Exomic sequencing of pancreatic NETs has revealed mutations in genes encoding either of the two subunits of a transcription/chromatin remodelling complex consisting of death-domain-associated protein (DAXX) and alpha thalassaemia/mental retardation syndrome X-linked (ATRX) in $43 \%$ of cases (Jiao et al. 2011). Inactivating mutations in the ATRX or DAXX genes are strongly correlated with the typical features of the telomeraseindependent telomere maintenance mechanism termed 'alternative lengthening of telomeres' (ALT) (Heaphy et al. 2011). Therefore, targeting ALT could be another therapeutic approach for those patients with pancreatic NETs, either alone or in combination with targeting telomerase (Shay et al. 2012).

On the basis of the results of a very recent study, loss of DAXX or ATRX protein and ALTs were concluded to be associated with chromosome instability and shorter survival times in patients with pancreatic NETs (Marinoni et al. 2014). In contrast, ALT probably is not an appropriate target in patients with small bowel NETs as exome sequencing did not detect mutations in the $D A X X$ or ATRX genes in these tumours (Banck et al. 2013).

\section{Tumour-promoting inflammation}

Research over the past decade has revealed, paradoxically, that the inflammatory response enhances tumourigenesis and progression (Hanahan \& Weinberg 2011). Interferon (IFN) was introduced in 1982 to treat patients with metastatic mid-gut NETs and carcinoid syndrome (Oberg et al. 1983). Possible mechanisms are the inhibition of cell proliferation, immune cell-mediated cytotoxicity,

Published by Bioscientifica Ltd 
inhibition of angiogenesis and reduction in tumour growth by blocking the cell cycle (Oberg 1992). Immune cells present at the tumour site were therefore thought to be an attempt by the immune system to eradicate tumours, but are increasingly acknowledged to play a role in tumour progression. For example, activation of nuclear factor $\kappa \mathrm{B}(\mathrm{NF} \kappa \mathrm{B})$ by the classical inhibitor-of-NF $\kappa \mathrm{B}$ kinase $\beta$ (IKK $\beta$ )-dependent pathway is a crucial mediator of inflammation-induced tumour growth and progression, as well as an important modulator of tumour surveillance and rejection (Karin \& Greten 2005). A case-control cohort study, including 50 GEP-NET patients, detected a difference in the insertion/deletion genotype of the NFkB1-94 ATTG promoter between patients with pNETs and those with carcinoid tumours (Burnik \& Yalcin 2009).

Several pro-inflammatory cytokines play a role in the development of NETs. Results from a study comparing pNET patients and healthy unrelated controls indicated an association between the high-expression C/T-511 IL1 $\beta$ (IL1B) genotype and susceptibility to pNETs (Cigrovski Berkovic et al. 2012). Interestingly, macrophage migration inhibitory factor (MIF) has been recently linked to neuroendocrine differentiation in prostate cancer (Tawadros et al. 2013). Immunotherapies are now being used clinically to inhibit several immune cell subsets that promote tumour development (Coussens et al. 2013).

In NETs, oncolytic viruses are being explored for their capacity to alter the immunosuppressive tumour microenvironment and activate immune effector cells (Essand et al. 2011). The oncolytic adenovirus Ad5 (CgA-E1AmiR122) has been shown to selectively replicate and kill neuroendocrine cells, including freshly isolated midgut carcinoid cells from liver metastases (Leja et al. 2011). The highly immunosuppressive microenvironment enables the oncolytic virus to replicate. This leads to a microbeassociated inflammatory response, which is optimal for antigen presentation by DCs. In addition, TAAs released from the dying tumour cells can be captured by the DCs. In order to enhance this effect even further, strategies have been developed to arm oncolytic viruses with immunestimulatory genes (Essand 2013). A phase I trial (NCT00314925) is being planned to study the side effects and the best dose of Seneca Valley virus-001 for the treatment of patients with advanced solid tumours with neuroendocrine features.

\section{Activating invasion and metastasis}

For the establishment of distant metastasis, loss of cellular adhesion, invasiveness, intravasation, extravasation and proliferation in the host organ are required. Loss of E-cadherin expression and function has been associated with disruption of E-cadherin junctions and gain of cell motility and invasiveness in several tumour types. Moreover, E-cadherin loss was identified in 13 out of 17 (76.5\%) gastric neuroendocrine carcinomas (NECs) and was significantly associated with lymph node metastasis; however, it did not correlate with invasion to adjacent organs or distant metastasis (Boo et al. 2007). Additionally, progressive loss of E-cadherin in tumour cells with nuclear $\beta$-catenin accumulation indicates that they have undergone an epithelial-mesenchymal transition - a developmental regulatory programme resulting in invasion, resistance to apoptosis and dissemination (Hanahan \& Weinberg 2011).

In one study cytoplasmic/nuclear $\beta$-catenin staining was observed in $79 \%$ of GI-NETs, and the genetic analysis showed a mutant $\beta$-catenin (S37A) in $37 \%$ of tumours. This mutation prevents its ubiquitination and prolongs its half-life compared with WT $\beta$-catenin. The authors did not find mutations in the other cases with positive $\beta$-catenin staining (nuclear/cytoplasmic), and presumably, its accumulation is due to other molecular alterations not yet identified (Fujimori et al. 2001). In another study it was observed that in those patients with GEP-NETs showing high SNAIL1 (SNAI1) protein levels, a cytoplasmic E-cadherin pattern, reduced $\mathrm{N}$-cadherin expression and loss of E-cadherin/ $\beta$-catenin adhesion complex integrity at the cell membrane, the 5-year survival rate was reduced (Galvan et al. 2013). Another important factor in the tumour invasion and metastasis process is the matrix metalloproteinase (MMP)/tissue inhibitor of metalloproteinase (TIMP) system. There are differences in the expression of MMP/TIMP between benign and malignant lesions (Jeffery et al. 2009), and MMP activity can be detected in cancer cells before the detection of extravascular metastasis (Zhang et al. 2010). The expression of MMP2 in pancreatic NETs (particularly in gastrinomas) could be used to characterise a malignant phenotype, whereas weak expression of MMP9 could indicate a less invasive phenotype (Gurevich 2003).

Src family kinases (SFK) are non-receptor tyrosine kinases that respond to mitogenic stimuli to interact with proteins involved in cell adhesion, motility and spreading. Up-regulation of SFK in pancreatic endocrine tumours has been confirmed, expression being higher in primary lesions than in metastases (Capurso et al. 2006, Di Florio et al. 2007). Moreover, the activation of SFK during cell adhesion stimulates the mTOR pathway and leads to increased cell cycle protein synthesis (Di Florio et al. 2011).

Published by Bioscientifica Ltd 
The inhibition of SFK by PP2 in cultured pancreatic cells caused a delay in cell adhesion and impaired the migration and colonisation process (Di Florio et al. 2007). Additionally, the inhibition of SFK prevents the up-regulation of the mTOR escape pathways usually triggered by mTOR inhibitors (Di Florio et al. 2011). The effects of Src inhibition have been studied on neuroendocrine cancer stem cells (N-CSCs), marked inhibition of tumour growth was observed (Gaur et al. 2011). These findings indicate potential new therapy strategies using mTOR and Src inhibitors together to reduce proliferation, cell adhesion and spreading of tumour cells.

\section{Inducing angiogenesis}

During tumour progression, the so-called 'angiogenic switch' is activated that promotes angiogenesis required for tumour growth (Hanahan \& Folkman 1996). Vascular endothelial growth factor (VEGF) is a key pro-angiogenic cytokine and crucial for NET carcinogenesis and progression. Patients with NETs have higher levels of circulating VEGF than control subjects, and those with progressive disease have higher levels than those with stable disease (Pavel et al. 2005, Zhang et al. 2007). There are conflicting results regarding whether pancreatic or midgut NETs have higher levels of VEGF (Terris et al. 1998, Bello et al. 2006). Low-grade NETs have extraordinary vascularisation, but it is diminished in more aggressive tumours (Marion-Audibert et al. 2003). In islet cell tumours, higher microvascular density (MVD) and VEGF (VEGFA) expression predict a more favourable prognosis (Couvelard et al. 2005) and this has been called the 'neuroendocrine paradox' (Scoazec 2013).

Treatment with a neutralising antibody to VEGF in mice with a duodenal carcinoid resulted in decreased tumour size and inhibition of liver metastasis (Konno et al. 1998). Furthermore, a MAB that blocks the VEGFA ligand and an antibody blocking the VEGF receptor subtype 2 have been tested in the RIP-Tag2 mouse model of insulinoma with consistent antiangiogenic effects on microvessel density, endothelial cell proliferation and anti-tumour activity with increased apoptosis (Casanovas et al. 2005, Sennino et al. 2012). The humanised anti-VEGF MAB, bevacizumab, reduced VEGF expression, MVD and tumour growth in a human carcinoid xenograft model, but does not affect the growth of carcinoid cells in vitro (Zhang et al. 2007).

Bevacizumab has been studied in patients with well-differentiated NETs in a phase II trial in combination with octreotide, achieving an $18 \%$ response rate (Yao et al. 2008b). A phase II study in combination with 2-methoxyestradiol revealed some degree of tumour reduction without achieving objective response according to RECIST response criteria (Kulke et al. 2011). Bevacizumab has also been studied in phase II trials in NETs in combination with temozolomide, with higher response rates observed in pancreatic NET G2 (Chan et al. 2012, Koumarianou et al. 2012) and in combination with oxaliplatin and capecitabine, reaching an objective response rate of $23 \%$ (Kunz et al. 2010). A randomised comparison of bevacizumab and octreotide vs IFN and octreotide is ongoing (NCT00569127).

Other proangiogenic growth factors are also important in tumour growth. Serum angiopoietin 2 (ANG2) and TIE2 levels are significantly elevated in patients with NETs compared with controls, and in patients with distant metastases compared with those without metastasis. Time to disease progression is shorter in patients with higher serum ANG2 levels (Srirajaskanthan et al. 2009, Detjen et al. 2010, Figueroa-Vega et al. 2010). Inhibitors of the TIE2 pathway are being evaluated in other solid tumours and may be worth exploring for NETs.

In human pNET samples, platelet-derived growth factor receptors $\alpha$ (PDGFR $\alpha$ (PDGFRA)) and $\beta$ (PDGFR $\beta$ (PDGFRB)) are commonly expressed both in tumour cells and tumour stroma (Fjallskog et al. 2003). Experimental studies with the RIP-Tag2 transgenic mouse model have demonstrated that dual blockage of endothelial cells and pericytes with VEGFR and PDGFR small molecule inhibitors results in a significant synergy (Pietras \& Hanahan 2005). Sunitinib (an inhibitor of both PDGFR and VEGFR) is approved for the treatment of G1 and G2 pNETs, after its use in a phase III trial resulted in an increase in patient progression-free survival (Raymond et al. 2011). It has also been tested in NETs from other locations (Kulke et al. 2008), and other tyrosine kinase receptor inhibitors such as pazopanib are currently being studied (Ahn et al. 2013). However, the emergence of resistance to antiangiogenic therapy remains a major clinical challenge, but may be reduced by the concurrent inhibition of c-Met (Sennino et al. 2012) or the combination of bevacizumab and tyrosine kinase inhibitors (Castellano et al. 2013).

Other angiogenesis inhibitors such as angiostatin and endostatin have been studied in the past and, although they have shown antiangiogenic and antitumour effects in various mouse models (Hanahan 1985, Bergers et al. 1999), these findings did not translate to humans in a phase II trial of endostatin in NETs (Kulke et al. 2006a). However, there are indirect antiangiogenic mechanisms that may provide a therapeutic target, such as the inhibition of the PI3K-AKT-mTOR pathway and the effect of SSAs.

Published by Bioscientifica Ltd. 
IFN also seems to have an antiangiogenic effect. In patients who have received IFN $\alpha$ treatment, liver metastasis biopsy material shows lower VEGF plasma levels and reduced VEGF mRNA levels and MVD (von Marschall et al. 2003). Thalidomide has been studied in two phase II trials in NETs, not reaching partial responses in monotherapy (Varker et al. 2008), but demonstrating promising activity in combination with temozolomide (Kulke et al. 2006b), although the mechanism is unclear.

Another important factor involved in angiogenesis is the hypoxia-inducible factor (HIF). In a series of 86 GEP-NETs, expression of HIF1 $\alpha$ (HIF1A) as measured by immunohistochemistry has proved in multivariate analysis to be a predictor of OS (Pinato et al. 2014). In another series of 24 ileal carcinoids, HIF1 $\alpha$ and HIF $2 \alpha$ were highly expressed. The HIF $2 \alpha$ expression was higher in metastases compared with the primary tumour in the same patient (Arvidsson et al. 2010). Heterozygous mutations in the $S D H(S D H B)$ gene activate the angiogenic pathway mediated by HIF1 $\alpha$ and VEGF, while $S D H D$ mutations may be involved in tumourigenesis of midgut carcinoids (Kytola et al. 2002).

\section{Genome instability and mutation}

Genome instability and mutation are considered to be basic characteristics of tumours that enable multistep progression, to which defects in caretaker mechanisms, mutations of genes involved in DNA repair mechanisms, chromatin remodelling and cell cycle control may all contribute. Genome instability can be best analysed by three molecular genetic approaches studying: i) microsatellite instability; ii) chromosomal instability and iii) methylation patterns including the $\mathrm{CpG}$ island methylator phenotype (CIMP) (Arnold et al. 2008). Poorly differentiated and aggressive metastatic tumours harbour more chromosomal alterations than their more differentiated counterparts. Methylation abnormalities including global hypomethylation of the genome (Karpathakis et al. 2013) and hypermethylation of tumour suppressor gene promoters leading to their inactivation have been described for a wide array of human malignancies (Robertson 2005).

Similar to other tumour entities, allelic imbalances are more frequent in poorly differentiated GI-NETs than in well-differentiated tumours (Furlan et al. 2004). Moreover, frequent TP53 alterations have also been described in these tumours (Lubensky \& Zhuang 2007). The chromosomal (comparative genome hybridisation) profiles of fore- and midgut NETs are different (Tonnies et al. 2001). When comparing fore/midgut NETs with poorly differentiated colorectal NETs, significant differences in microsatellite instability have not been detected. But CIMP was more abundant in poorly differentiated colorectal NETs (Arnold et al. 2008). Microsatellite instability appears to be an infrequent event in intestinal NETs (Kidd et al. 2005, Arnold et al. 2007, 2008). CIMP-negative NETs of the foregut and midgut had a better clinical outcome than their CIMP-positive counterparts and this finding has also been associated with Ki-67 positivity (Arnold et al. 2007). Hypermethylation of the promoters of RAS association 148 domain gene family 1 (RASSF1) and cyclin-dependent kinase inhibitor 2a/p16INK4a tumour suppressor genes has been noticed both in pancreatic and other GI-NETs (Karpathakis et al. 2013).

Benign insulinomas have been associated with an increased methylation rate (Arnold et al. 2007). Hypermethylation of the differentially methylated region 2 (DMR2) regulating the expression of the insulin-like growth factor 2 (IGF2)/H19 locus and over-expression of IGF2 has been described in insulinoma (Dejeux et al. 2009). IGF2 over-expression may contribute to growth of insulinomas similar to other tumours, such as adrenocortical cancer (Bertherat \& Bertagna 2009).

Differences between pancreatic and small intestinal NETs have been observed at several levels. In contrast to small intestinal NETs, high levels of microsatellite instability have been reported in two studies of pNET, and this has been associated with the inactivation of the mutL homologue 1 (MLH1) gene (Mei et al. 2009). Methylation profiles of NETs of pancreatic and intestinal origin are also different (Chan et al. 2003). Novel studies using the next-generation sequencing approaches underline the relevance of somatic mutations in both small intestinal and pancreatic NETs, but the spectra of mutations are different. In small intestinal NETs, frameshift mutations and hemizygous deletions of the cell cycle regulator cyclin-dependent kinase inhibitor $1 \mathrm{~B}$, alternatively p27 (CDKN1B) gene have been found (Francis, et al. 2013). In contrast to intestinal NETs, pancreatic NETs are more likely to be associated with rare hereditary tumour syndromes including multiple endocrine neoplasia type 1 (MEN1), VHL disease and tuberous sclerosis (TSC). Somatic mutations of the MEN1 gene have been found in $44 \%$ of PNET samples (Jiao et al. 2011). The protein product of the tumour suppressor MEN1 gene, menin, interacts with mixed lineage leukaemia (MLL (KMT2A)) proteins, having histone-modulating methyltransferase activity (Yokoyama et al. 2004). As noted earlier, somatic mutations in the DAXX and ATRX genes that are also pivotal in the regulation of chromatin remodelling have

Published by Bioscientifica Ltd 
been noted in $43 \%$ of pNET cases, but these are absent from intestinal NETs (Jiao et al. 2011). Somatic mutations of TSC2 and PTEN tumour suppressor genes involved in the mTOR pathway have also been noted in $14 \%$ of pNETs (Jiao et al. 2011). All these observations are indicative of major differences in the molecular pathogenesis of pancreatic and intestinal NETs.

In vitro experiments on cell lines have the potential to produce novel therapeutic options (Larsson 2013). Epigenetic mechanisms might be of interest, as they are potentially reversible (Karpathakis et al. 2013). Inhibition of DNA methyltransferases, for example with azacytidine or via histone deacetylation (valproic acid, sodium butyrate, MS-275 (a synthetic benzamide) and trichostatin A), seems to be effective in GEP-NET cell lines; however, there are no results regarding clinical applications as yet (Larsson 2013).

\section{Resisting cell death}

Evasion of cell death is one of the hallmarks of human cancers, which promotes tumour formation and progression as well as treatment resistance.

Several tumour suppressor genes and oncogenes involved in the pathogenesis of GEP-NETs have a major role in the modulation of cell death. Most of these genetic and epigenetic alterations over-activate Akt-mTOR signalling (Ciuffreda et al. 2010) and promote resistance to cell death. In contrast, mTOR hyper-activation represents an important target for cancer therapy. Everolimus is an oral mTOR inhibitor that has been extensively studied for NETs (Yao et al. 2008b, 2011, Pavel et al. 2011, Faggiano et al. 2012). However, the emergence of drug resistance may limit the utility of mTOR inhibitors (Carew et al. 2011). mTOR signalling consists of two distinct complexes: mTORC1 and mTORC2. In NET cells, everolimus blocks mTORC1 activity but does not alter the mTORC2 complex at nanomolar concentrations. Thus, it is possible that inhibition of mTORC1 shifts the balance to increased mTORC2 activity, which has been shown to activate Akt directly (Sarbassov et al. 2005) or through up-regulation of IGF1 signalling (Tamburini et al. 2008). These results provide a strong rationale for dual targeting of mTORC1 and PI3K activity (Zitzmann et al. 2010).

Another potential approach to reverse resistance to mTOR inhibitors is the use of SSAs through suppression of PI3K-Akt signalling (Bousquet et al. 2012). Significant clinical improvement has recently been observed after treatment with everolimus and octreotide LAR in NET patients (Pavel et al. 2011) and the tolerability of everolimus combined with pasireotide is currently under investigation (NCT00804336).

\section{Dysregulating cellular energetics}

In normal cells, energy is mainly produced by oxidative phosphorylation of glucose, but in cancer cells energy metabolism is characterised by increased glycolysis and lactate production, even under aerobic conditions, known as the Warburg effect. The amount of ATP production is much lower in glycolysis compared with oxidative phosphorylation, therefore cancer cells compensate for this lower efficiency by increasing glucose uptake - this can be visualised using fludeoxyglucose positron emission tomography (FDG-PET). In NETs, FDG-PET positivity is associated with a high proliferation rate and poor prognosis (Binderup et al. 2010).

In recent years, there has been renewed interest in metformin, a drug that has been used for decades to treat type II diabetes but may have anticancer properties. Metformin usage has been associated with better survival in diabetic pancreatic cancer patients (Sadeghi et al. 2012) and with a greater likelihood of complete pathological tumour response following neo-adjuvant chemotherapy in diabetic breast cancer patients. Metformin reduces insulin resistance in patients with type II diabetes and thus lowers levels of insulin and IGFs, which may contribute to its anti-cancer effects. Metformin also activates AMPK, which results in the inhibition of mTOR signalling (Jalving et al. 2010). Thus, the combination of metformin and everolimus or temsirolimus could result in synergistic tumour growth inhibition and abrogate the hyperglycaemia caused by mTOR inhibitors. Results of a phase I trial of metformin and temsirolimus in advanced cancer have been published (MacKenzie et al. 2012), with further ongoing clinical trials of the mTOR inhibitor/metformin combination in advanced cancer. However, there are no clinical trials of metformin as a monotherapy or in combination therapy in patients with GEP-NETs.

\section{Conclusions and perspectives}

The pre-clinical and clinical results reviewed in this study not only support the notion that the 'hallmarks of cancer' are relevant to NETs, but also highlight the fact that little research has been done in certain areas that may be of potential therapeutic value.

As in other cancers, allelic imbalances, TP53 alterations, CIMP and increased telomerase activity are more frequent in poorly differentiated GI-NETs than in

Published by Bioscientifica Ltd. 
well-differentiated tumours; however, microsatellite instability appears to be an infrequent event in intestinal NETs. Whole-genome sequencing of both germline and tumour DNA is expected to generate more precise data about the molecular pathogenesis of endocrine cancers.

Sustained proliferation signalling plays an important role in tumourigenesis, from hyperplasia to neoplasia, at least in gastric NET types 1 and 2. However, hyperplasic cells have been found at the periphery of NETs in the appendix and intestine, indicating a similar process of tumourigenesis but the proliferation signalling pathways in these tumours are not yet fully elucidated.

It has been demonstrated that blocking the gastrinmediated proliferation signal may lead to complete tumour regression in gastric NETs, and the results of phase II and phase III studies with blockers of EGFR (erlotinib and gefitinib)-mediated proliferation pathways and with dual-blockers of PI3K-Akt/mTOR pathways are expected to define its usefulness in treating NETs.

Progress has also been made in the exploration of signalling pathways mediated by GCPR, with interesting results for the development of diagnostic tools such as scintigraphy with SST or GLP1 analogues, and therapeutic strategies either by selective agonism of SSTRs or blocking CCK2 receptors, for example.

Another hallmark of cancer demonstrated in NETs is the capability to evade growth control mechanisms mediated by tumour suppressor genes such as VHL, TSC, NF1, MEN1 and RB among others. Based on preclinical experiments, results indicate the potential of gene therapy for the induction of expression of suppressor genes, such as menin in NET patients who are carriers of inactivating mutations.

Additionally, results of recent experiments have confirmed the ability of NET cells to evade control by the immune system and their ability to induce inflammation to promote greater infiltration. Studies are being performed with immunomodulatory molecules and modified $\mathrm{T}$ cells to stimulate the immune system in order to induce regression in NETs.

Regarding invasion and metastasis, results from recent studies have challenged the established clonal evolution theory of tumourigenesis, and different models have been proposed to explain the early metastatic outgrowth of less immunogenic tumour cells without the mutations of the primary tumour cells, with the possibility of the early migration of a subset of stem-like cancer cells. Additionally, some changes such as reduced expression of E-cadherin, B-catenin mutations, differential MMP protein activity (i.e. more MMP2 and less MMP9 activity) and up-regulation of SFK observed in metastatic NET-derived cells require further evaluation as therapeutic targets.

Finally, angiogenesis has been well studied in NETs, as a fundamental process in malignant transformation, tumour growth and progression. Results of many studies have indicated that VEGF expression is a prognostic factor and an interesting target for molecular therapy. At present, there are many ongoing clinical trials of angiogenesis inhibitors (including valatanib, thalidomide, pazopanib, JI-101, dovitinib, atiprimod and sorafenib) and many others are being evaluated in pre-clinical trials (for example, AF-493-NA, DC101, bevacizumab and ZK 304709). The results from these studies will be required to demonstrate that it is possible to overcome potential antiangiogenic resistance and produce long-term clinical benefit in NET patients.

\section{Supplementary data}

This is linked to the online version of the paper at http://dx.doi.org/10.1530/ ERC-14-0106.

\section{Declaration of interest}

The authors declare that there is no conflict of interest that could be perceived as prejudicing the impartiality of the review.

\section{Funding}

This manuscript is the result of a Knowledge Network collaborative project, sponsored by Ipsen Ltd.

\section{Author contribution statement}

All authors contributed equally to this work.

\section{Acknowledgements}

The authors wish to thank Dr Scott Gouveia of echogroup, UK, for editorial assistance funded by Ipsen.

\section{References}

Abe BT \& Macian F 2013 Uncovering the mechanisms that regulate tumorinduced T-cell anergy. Oncoimmunology 2 e22679. (doi:10.4161/onci. 22679)

Ahn HK, Choi JY, Kim KM, Kim H, Choi SH, Park SH, Park JO, Lim HY, Kang WK, Lee J et al. 2013 Phase II study of pazopanib monotherapy in metastatic gastroenteropancreatic neuroendocrine tumours. British Journal of Cancer 109 1414-1419. (doi:10.1038/bjc.2013.470)

Ameri P \& Ferone D 2012 Diffuse endocrine system, neuroendocrine tumors and immunity: what's new? Neuroendocrinology 95 267-276. (doi:10.1159/000334612) http://erc.endocrinology-journals.org DOI: 10.1530/ERC-14-0106
(C) 2014 Society for Endocrinology Printed in Great Britain
Published by Bioscientifica Ltd 
Anlauf M, Perren A \& Kloppel G 2007 Endocrine precursor lesions and microadenomas of the duodenum and pancreas with and without MEN1: criteria, molecular concepts and clinical significance. Pathobiology 74 279-284. (doi:10.1159/000105810)

Arnold CN, Sosnowski A, Schmitt-Graff A, Arnold R \& Blum HE 2007 Analysis of molecular pathways in sporadic neuroendocrine tumors of the gastro-entero-pancreatic system. International Journal of Cancer 120 2157-2164. (doi:10.1002/ijc.22569)

Arnold CN, Nagasaka T, Goel A, Scharf I, Grabowski P, Sosnowski A, Schmitt-Graff A, Boland CR, Arnold R \& Blum HE 2008 Molecular characteristics and predictors of survival in patients with malignant neuroendocrine tumors. International Journal of Cancer 123 1556-1564. (doi:10.1002/ijc.23690)

Arvidsson Y, Bergstrom A, Arvidsson L, Kristiansson E, Ahlman H \& Nilsson O 2010 Hypoxia stimulates CXCR4 signalling in ileal carcinoids. Endocrine-Related Cancer 17 303-316. (doi:10.1677/ ERC-09-0085)

Banck MS, Kanwar R, Kulkarni AA, Boora GK, Metge F, Kipp BR, Zhang L, Thorland EC, Minn KT, Tentu R et al. 2013 The genomic landscape of small intestine neuroendocrine tumors. Journal of Clinical Investigation 123 2502-2508. (doi:10.1172/JCI67963)

Bello C, Deprimo SE, Friece C, Smeraglia J, Sherman L, Tye L, Baum C, Meropol NJ, Lenz H \& Kulke MH 2006 Analysis of circulating biomarkers of sunitinib malate in patients with unresectable neuroendocrine tumors (NET): VEGF, IL-8, and soluble VEGF receptors 2 and 3. ASCO Meeting Abstracts 244045

Bergers G, Javaherian K, Lo KM, Folkman J \& Hanahan D 1999 Effects of angiogenesis inhibitors on multistage carcinogenesis in mice. Science 284 808-812. (doi:10.1126/science.284.5415.808)

Bertherat J \& Bertagna X 2009 Pathogenesis of adrenocortical cancer. Best Practice \& Research. Clinical Endocrinology \& Metabolism 23 261-271. (doi:10.1016/j.beem.2008.10.006)

Binderup T, Knigge U, Loft A, Mortensen J, Pfeifer A, Federspiel B, Hansen CP, Hojgaard L \& Kjaer A 2010 Functional imaging of neuroendocrine tumors: a head-to-head comparison of somatostatin receptor scintigraphy, ${ }^{123}$ I-MIBG scintigraphy, and ${ }^{18}$ F-FDG PET. Journal of Nuclear Medicine 51 704-712. (doi:10.2967/jnumed.109.069765)

Bockhorn M, Frilling A, Clauer U, Hertl M \& Broelsch CE 2000 Telomerase activity in neuroendocrine tumors. International Journal of Surgical Investigation 2 219-225.

Boo YJ, Park SS, Kim JH, Mok YJ, Kim SJ \& Kim CS 2007 Gastric neuroendocrine carcinoma: clinicopathologic review and immunohistochemical study of E-cadherin and Ki-67 as prognostic markers. Journal of Surgical Oncology 95 110-117. (doi:10.1002/jso.20616)

Bousquet C, Lasfargues C, Chalabi M, Billah SM, Susini C, Vezzosi D, Caron P \& Pyronnet S 2012 Clinical review: current scientific rationale for the use of somatostatin analogs and mTOR inhibitors in neuroendocrine tumor therapy. Journal of Clinical Endocrinology and Metabolism 97 727-737. (doi:10.1210/jc.2011-2088)

Brahmer JR, Tykodi SS, Chow LQ, Hwu WJ, Topalian SL, Hwu P, Drake CG, Camacho LH, Kauh J, Odunsi K et al. 2012 Safety and activity of anti-PD-L1 antibody in patients with advanced cancer. New England Journal of Medicine 366 2455-2465. (doi:10.1056/NEJMoa1200694)

Burnik FS \& Yalcin S 2009 NFKB1 -94 insertion/deletion ATTG polymorphism in gastroenteropancreatic neuroendocrine tumors. Chemotherapy 55 381-385. (doi:10.1159/000237744)

Cakir M, Dworakowska D \& Grossman A 2010a Somatostatin receptor biology in neuroendocrine and pituitary tumours: part 1 - molecular pathways. Journal of Cellular and Molecular Medicine 14 2570-2584. (doi:10.1111/j.1582-4934.2010.01125.x)

Cakir M, Dworakowska D \& Grossman A $2010 b$ Somatostatin receptor biology in neuroendocrine and pituitary tumours: part 2 - clinical implications. Journal of Cellular and Molecular Medicine 14 2585-2591. (doi:10.1111/j.1582-4934.2010.01125_1.x)

Caplin M, Ruszniewski P, Pavel M, Cwikla J, Phan A, Raderer M, Sedlackova E, Cadiot G, Wall L, Rindi G et al. 2014 Lanreotide in metastatic enteropancreatic neuroendocrine tumors. New England Journal of Medicine 371 224-233. (doi:10.1056/NEJMoa1316158)

Capurso G, Lattimore S, Crnogorac-Jurcevic T, Panzuto F, Milione M, Bhakta V, Campanini N, Swift SM, Bordi C, Delle Fave G et al. 2006 Gene expression profiles of progressive pancreatic endocrine tumours and their liver metastases reveal potential novel markers and therapeutic targets. Endocrine-Related Cancer 13 541-558. (doi:10.1677/ erc.1.01153)

Carew JS, Kelly KR \& Nawrocki ST 2011 Mechanisms of mTOR inhibitor resistance in cancer therapy. Targeted Oncology 6 17-27. (doi:10.1007/ s11523-011-0167-8)

Casanovas O, Hicklin DJ, Bergers G \& Hanahan D 2005 Drug resistance by evasion of antiangiogenic targeting of VEGF signaling in late-stage pancreatic islet tumors. Cancer Cell 8 299-309. (doi:10.1016/j.ccr.2005. 09.005)

Castellano D, Capdevila J, Sastre J, Alonso V, Llanos M, Garcia-Carbonero R, Manzano Mozo JL, Sevilla I, Duran I \& Salazar R 2013 Sorafenib and bevacizumab combination targeted therapy in advanced neuroendocrine tumour: a phase II study of Spanish Neuroendocrine Tumour Group (GETNE0801). European Journal of Cancer 49 3780-3787. (doi:10.1016/j.ejca.2013.06.042)

Cescato R, Schulz S, Waser B, Eltschinger V, Rivier JE, Wester HJ, Culler M, Ginj M, Liu Q, Schonbrunn A et al. 2006 Internalization of sst2, sst3, and sst5 receptors: effects of somatostatin agonists and antagonists. Journal of Nuclear Medicine 47 502-511.

Chan AO, Kim SG, Bedeir A, Issa JP, Hamilton SR \& Rashid A 2003 CpG island methylation in carcinoid and pancreatic endocrine tumors. Oncogene 22 924-934. (doi:10.1038/sj.onc.1206123)

Chan JA, Stuart K, Earle CC, Clark JW, Bhargava P, Miksad R, Blaszkowsky L, Enzinger PC, Meyerhardt JA, Zheng H et al. 2012 Prospective study of bevacizumab plus temozolomide in patients with advanced neuroendocrine tumors. Journal of Clinical Oncology 30 2963-2968. (doi:10.1200/JCO.2011.40.3147)

Christ E, Wild D, Forrer F, Brandle M, Sahli R, Clerici T, Gloor B, Martius F, Maecke H \& Reubi JC 2009 Glucagon-like peptide-1 receptor imaging for localization of insulinomas. Journal of Clinical Endocrinology and Metabolism 94 4398-4405. (doi:10.1210/jc.2009-1082)

Cigrovski Berkovic M, Catela Ivkovic T, Marout J, Zjacic-Rotkvic V \& Kapitanovic S 2012 Interleukin $1 \beta$ gene single-nucleotide polymorphisms and susceptibility to pancreatic neuroendocrine tumors. DNA and Cell Biology 31 531-536. (doi:10.1089/dna.2011.1317)

Cingarlini S, Bonomi M, Corbo V, Scarpa A \& Tortora G 2012 Profiling mTOR pathway in neuroendocrine tumors. Targeted Oncology 7 183-188. (doi:10.1007/s11523-012-0226-9)

Ciuffreda L, Di Sanza C, Incani UC \& Milella M 2010 The mTOR pathway: a new target in cancer therapy. Current Cancer Drug Targets 10 484-495. (doi:10.2174/156800910791517172)

Coussens LM, Zitvogel L \& Palucka AK 2013 Neutralizing tumorpromoting chronic inflammation: a magic bullet? Science 339 286-291. (doi:10.1126/science.1232227)

Couvelard A, O'Toole D, Turley H, Leek R, Sauvanet A, Degott C, Ruszniewski P, Belghiti J, Harris AL, Gatter K et al. 2005 Microvascular density and hypoxia-inducible factor pathway in pancreatic endocrine tumours: negative correlation of microvascular density and VEGF expression with tumour progression. British Journal of Cancer 92 94-101. (doi:10.1038/sj.bjc.6602245)

Cui T, Tsolakis AV, Li SC, Cunningham JL, Lind T, Oberg K \& Giandomenico V 2013 Olfactory receptor 51E1 protein as a potential novel tissue biomarker for small intestine neuroendocrine carcinomas. European Journal of Endocrinology 168 253-261. (doi:10.1530/EJE-12-0814)

Dejeux E, Olaso R, Dousset B, Audebourg A, Gut IG, Terris B \& Tost J 2009 Hypermethylation of the IGF2 differentially methylated region 2 is a specific event in insulinomas leading to loss-of-imprinting and overexpression. Endocrine-Related Cancer 16 939-952. (doi:10.1677/ ERC-08-0331) http://erc.endocrinology-journals.org DOI: 10.1530/ERC-14-0106 (c) 2014 Society for Endocrinology Printed in Great Britain 
Detjen KM, Rieke S, Deters A, Schulz P, Rexin A, Vollmer S, Hauff P, Wiedenmann B, Pavel M \& Scholz A 2010 Angiopoietin-2 promotes disease progression of neuroendocrine tumors. Clinical Cancer Research 16 420-429. (doi:10.1158/1078-0432.CCR-09-1924)

Diakatou E, Kaltsas G, Tzivras M, Kanakis G, Papaliodi E \& Kontogeorgos G 2011 Somatostatin and dopamine receptor profile of gastroenteropancreatic neuroendocrine tumors: an immunohistochemical study. Endocrine Pathology 22 24-30. (doi:10.1007/s12022-011-9149-8)

Di Florio A, Capurso G, Milione M, Panzuto F, Geremia R, Delle Fave G \& Sette C 2007 Src family kinase activity regulates adhesion, spreading and migration of pancreatic endocrine tumour cells. Endocrine-Related Cancer 14 111-124. (doi:10.1677/erc.1.01318)

Di Florio A, Adesso L, Pedrotti S, Capurso G, Pilozzi E, Corbo V, Scarpa A, Geremia R, Delle Fave G \& Sette C 2011 Src kinase activity coordinates cell adhesion and spreading with activation of mammalian target of rapamycin in pancreatic endocrine tumour cells. Endocrine-Related Cancer 18 541-554. (doi:10.1530/ERC-10-0153)

Duran-Prado M, Malagon MM, Gracia-Navarro F \& Castano JP 2008 Dimerization of $\mathrm{G}$ protein-coupled receptors: new avenues for somatostatin receptor signalling, control and functioning. Molecular and Cellular Endocrinology 286 63-68. (doi:10.1016/j.mce.2007.12.006)

ENETS 2008 ENETS Consensus Guidelines for the Diagnosis and Treatment of Neuroendocrine Gastrointestinal Tumors. Neuroendocrinology $\mathbf{8 7}$ No. 1. pp. 1-64. Eds WW de Herder, D O’Toole, G Rindi \& B Wiedenmann. Basel: S Karger.

Essand M 2013 Virotherapy of neuroendocrine tumors. Neuroendocrinology 97 26-34. (doi:10.1159/000336084)

Essand M, Leja J, Giandomenico V \& Oberg KE 2011 Oncolytic viruses for the treatment of neuroendocrine tumors. Hormone and Metabolic Research 43 877-883. (doi:10.1055/s-0031-1277225)

Faggiano A, Ramundo V, Dicitore A, Castiglioni S, Borghi MO, Severino R, Ferolla P, Crino L, Abbruzzese A, Sperlongano P et al. 2012 Everolimus is an active agent in medullary thyroid cancer: a clinical and in vitro study. Journal of Cellular and Molecular Medicine 16 1563-1572. (doi:10.1111/ j.1582-4934.2011.01438.x)

Figueroa-Vega N, Diaz A, Adrados M, Alvarez-Escola C, Paniagua A, Aragones J, Martin-Perez E, Leskela S, Moreno-Otero R, GonzalezAmaro R et al. 2010 The association of the angiopoietin/Tie-2 system with the development of metastasis and leukocyte migration in neuroendocrine tumors. Endocrine-Related Cancer 17 897-908. (doi:10.1677/ERC-10-0020)

Fjallskog ML, Lejonklou MH, Oberg KE, Eriksson BK \& Janson ET 2003 Expression of molecular targets for tyrosine kinase receptor antagonists in malignant endocrine pancreatic tumors. Clinical Cancer Research 9 1469-1473.

Fossmark R, Sordal O, Jianu CS, Qvigstad G, Nordrum IS, Boyce M \& Waldum HL 2012 Treatment of gastric carcinoids type 1 with the gastrin receptor antagonist netazepide (YF476) results in regression of tumours and normalisation of serum chromogranin A. Alimentary Pharmacology \& Therapeutics 36 1067-1075. (doi:10.1111/apt.12090)

Francis JM, Kiezun A, Ramos AH, Serra S, Pedamallu CS, Qian ZR, Banck MS, Kanwar R, Kulkarni AA, Karpathakis A et al. 2013 Somatic mutation of CDKN1B in small intestine neuroendocrine tumors. Nature Genetics $\mathbf{4 5}$ 1483-1486. (doi:10.1038/ng.2821)

Froberg AC, de Jong M, Nock BA, Breeman WA, Erion JL, Maina T, Verdijsseldonck M, de Herder WW, van der Lugt A, Kooij PP et al. 2009 Comparison of three radiolabelled peptide analogues for CCK-2 receptor scintigraphy in medullary thyroid carcinoma. European Journal of Nuclear Medicine and Molecular Imaging 36 1265-1272. (doi:10.1007/s00259-009-1098-9)

Fujimori M, Ikeda S, Shimizu Y, Okajima M \& Asahara T 2001 Accumulation of $\beta$-catenin protein and mutations in exon 3 of $\beta$-catenin gene in gastrointestinal carcinoid tumor. Cancer Research $\mathbf{6 1}$ 6656-6659.

Furlan D, Cerutti R, Uccella S, La Rosa S, Rigoli E, Genasetti A \& Capella C 2004 Different molecular profiles characterize well-differentiated endocrine tumors and poorly differentiated endocrine carcinomas of the gastroenteropancreatic tract. Clinical Cancer Research 10 947-957. (doi:10.1158/1078-0432.CCR-1068-3)

Galvan JA, Astudillo A, Vallina A, Fonseca PJ, Gomez-Izquierdo L, GarciaCarbonero R \& Gonzalez MV 2013 Epithelial-mesenchymal transition markers in the differential diagnosis of gastroenteropancreatic neuroendocrine tumors. American Journal of Clinical Pathology 140 61-72. (doi:10.1309/AJCPIV40ISTBXRAX)

Gatto F \& Hofland LJ 2011 The role of somatostatin and dopamine D2 receptors in endocrine tumors. Endocrine-Related Cancer 18 R233-R251. (doi:10.1530/ERC-10-0334)

Gaur P, Sceusi EL, Samuel S, Xia L, Fan F, Zhou Y, Lu J, Tozzi F, LopezBerestein G, Vivas-Mejia P et al. 2011 Identification of cancer stem cells in human gastrointestinal carcinoid and neuroendocrine tumors. Gastroenterology 141 1728-1737. (doi:10.1053/j.gastro.2011.07.037)

Giandomenico V, Cui T, Grimelius L, Oberg K, Pelosi G \& Tsolakis AV 2013 Olfactory receptor $51 \mathrm{E} 1$ as a novel target for diagnosis in somatostatin receptor-negative lung carcinoids. Journal of Molecular Endocrinology $\mathbf{5 1}$ 277-286. (doi:10.1530/JME-13-0144)

Gomez-Roman JJ, Romero AF, Castro LS, Nieto EH, Fernandez-Luna JL \& Val-Bernal JF 2000 Telomerase activity in pulmonary neuroendocrine tumors: correlation with histologic subtype (MS-0060). American Journal of Surgical Pathology 24 417-421. (doi:10.1097/00000478200003000-00011)

Grossrubatscher E, Veronese S, Ciaramella PD, Pugliese R, Boniardi M, De Carlis L, Torre M, Ravini M, Gambacorta M \& Loli P 2008 High expression of dopamine receptor subtype 2 in a large series of neuroendocrine tumors. Cancer Biology \& Therapy 7 1970-1978. (doi:10.4161/cbt.7.12.6957)

Gurevich LE 2003 Role of matrix metalloproteinases 2 and 9 in determination of invasive potential of pancreatic tumors. Bulletin of Experimental Biology and Medicine 136 494-498. (doi:10.1023/B:BEBM. 0000017103.79321.0b)

Hanahan D 1985 Heritable formation of pancreatic $\beta$-cell tumours in transgenic mice expressing recombinant insulin/simian virus 40 oncogenes. Nature 315 115-122. (doi:10.1038/315115a0)

Hanahan D \& Folkman J 1996 Patterns and emerging mechanisms of the angiogenic switch during tumorigenesis. Cell 86 353-364. (doi:10.1016/S0092-8674(00)80108-7)

Hanahan D \& Weinberg RA 2000 The hallmarks of cancer. Cell 100 57-70. (doi:10.1016/S0092-8674(00)81683-9)

Hanahan D \& Weinberg RA 2011 Hallmarks of cancer: the next generation. Cell 144 646-674. (doi:10.1016/j.cell.2011.02.013)

Heaphy CM, de Wilde RF, Jiao Y, Klein AP, Edil BH, Shi C, Bettegowda C, Rodriguez FJ, Eberhart CG, Hebbar S et al. 2011 Altered telomeres in tumors with ATRX and DAXX mutations. Science 333425. (doi:10.1126/science.1207313)

Hodi FS, O'Day SJ, McDermott DF, Weber RW, Sosman JA, Haanen JB, Gonzalez R, Robert C, Schadendorf D, Hassel JC et al. 2010 Improved survival with ipilimumab in patients with metastatic melanoma. New England Journal of Medicine 363 711-723. (doi:10.1056/ NEJMoa1003466)

House MG, Herman JG, Guo MZ, Hooker CM, Schulick RD, Lillemoe KD, Cameron JL, Hruban RH, Maitra A \& Yeo CJ 2003 Aberrant hypermethylation of tumor suppressor genes in pancreatic endocrine neoplasms. Annals of Surgery 238 423-431.

Hu W, Feng Z, Modica I, Klimstra DS, Song L, Allen PJ, Brennan MF, Levine AJ \& Tang LH 2010 Gene amplifications in well-differentiated pancreatic neuroendocrine tumors inactivate the p53 pathway. Genes \& Cancer 1 360-368. (doi:10.1177/1947601910371979)

Jalving M, Gietema JA, Lefrandt JD, de Jong S, Reyners AK, Gans RO \& de Vries EG 2010 Metformin: taking away the candy for cancer? European Journal of Cancer 46 2369-2380. (doi:10.1016/j.ejca.2010. 06.012)

Jeffery N, McLean MH, El-Omar EM \& Murray GI 2009 The matrix metalloproteinase/tissue inhibitor of matrix metalloproteinase profile 
in colorectal polyp cancers. Histopathology 54 820-828. (doi:10.1111/ j.1365-2559.2009.03301.x)

Jiao Y, Shi C, Edil BH, de Wilde RF, Klimstra DS, Maitra A, Schulick RD, Tang LH, Wolfgang CL, Choti MA et al. 2011 DAXX/ATRX, MEN1, and mTOR pathway genes are frequently altered in pancreatic neuroendocrine tumors. Science 331 1199-1203. (doi:10.1126/science.1200609)

Karin M \& Greten FR 2005 NF-кB: linking inflammation and immunity to cancer development and progression. Nature Reviews. Immunology $\mathbf{5}$ 749-759. (doi:10.1038/nri1703)

Karpathakis A, Dibra H \& Thirlwell C 2013 Neuroendocrine tumours: cracking the epigenetic code. Endocrine-Related Cancer 20 R65-R82. (doi:10.1530/ERC-12-0338)

Katsenelson NS, Shurin GV, Bykovskaia SN, Shogan J \& Shurin MR 2001 Human small cell lung carcinoma and carcinoid tumor regulate dendritic cell maturation and function. Modern Pathology 14 40-45. (doi:10.1038/modpathol.3880254)

Kidd M, Eick G, Shapiro MD, Camp RL, Mane SM \& Modlin IM 2005 Microsatellite instability and gene mutations in transforming growth factor- $\beta$ type II receptor are absent in small bowel carcinoid tumors. Cancer 103 229-236. (doi:10.1002/cncr.20750)

Konno H, Arai T, Tanaka T, Baba M, Matsumoto K, Kanai T, Nakamura S, Baba S, Naito Y, Sugimura H et al. 1998 Antitumor effect of a neutralizing antibody to vascular endothelial growth factor on liver metastasis of endocrine neoplasm. Japanese Journal of Cancer Research 89 933-939. (doi:10.1111/j.1349-7006.1998.tb00651.x)

Korner M, Stockli M, Waser B \& Reubi JC 2007 GLP-1 receptor expression in human tumors and human normal tissues: potential for in vivo targeting. Journal of Nuclear Medicine $\mathbf{4 8}$ 736-743. (doi:10.2967/jnumed. 106.038679)

Koumarianou A, Antoniou S, Kanakis G, Economopoulos N, Rontogianni D, Ntavatzikos A, Tsavaris N, Pectasides D, Dimitriadis G \& Kaltsas G 2012 Combination treatment with metronomic temozolomide, bevacizumab and long-acting octreotide for malignant neuroendocrine tumours. Endocrine-Related Cancer 19 L1-L4. (doi:10.1530/ ERC-11-0287)

Krausch M, Raffel A, Anlauf M, Schott M, Willenberg H, Lehwald N, Hafner D, Cupisti K, Eisenberger CF \& Knoefel WT 2011 Loss of PTEN expression in neuroendocrine pancreatic tumors. Hormone and Metabolic Research 43 865-871. (doi:10.1055/s-0031-1291333)

Kulke MH, Bergsland EK, Ryan DP, Enzinger PC, Lynch TJ, Zhu AX, Meyerhardt JA, Heymach JV, Fogler WE, Sidor C et al. 2006a Phase II study of recombinant human endostatin in patients with advanced neuroendocrine tumors. Journal of Clinical Oncology 24 3555-3561. (doi:10.1200/JCO.2006.05.6762)

Kulke MH, Stuart K, Enzinger PC, Ryan DP, Clark JW, Muzikansky A, Vincitore M, Michelini A \& Fuchs CS 2006b Phase II study of temozolomide and thalidomide in patients with metastatic neuroendocrine tumors. Journal of Clinical Oncology 24 401-406. (doi:10.1200/JCO.2005.03.6046)

Kulke MH, Lenz HJ, Meropol NJ, Posey J, Ryan DP, Picus J, Bergsland E, Stuart K, Tye L, Huang X et al. 2008 Activity of sunitinib in patients with advanced neuroendocrine tumors. Journal of Clinical Oncology $\mathbf{2 6}$ 3403-3410. (doi:10.1200/JCO.2007.15.9020)

Kulke MH, Chan JA, Meyerhardt JA, Zhu AX, Abrams TA, Blaszkowsky LS, Regan E, Sidor C \& Fuchs CS 2011 A prospective phase II study of 2-methoxyestradiol administered in combination with bevacizumab in patients with metastatic carcinoid tumors. Cancer Chemotherapy and Pharmacology 68 293-300. (doi:10.1007/s00280-010-1478-7)

Kunz PL, Kuo T, Zahn JM, Kaiser HL, Norton JA, Visser BC, Longacre TA, Ford JM, Balise RR \& Fisher GA 2010 A phase II study of capecitabine, oxaliplatin, and bevacizumab for metastatic or unresectable neuroendocrine tumors. ASCO Meeting Abstracts 284104.

Kvols LK, Oberg KE, O'Dorisio TM, Mohideen P, de Herder WW, Arnold R, Hu K, Zhang Y, Hughes G, Anthony L et al. 2012 Pasireotide (SOM230) shows efficacy and tolerability in the treatment of patients with advanced neuroendocrine tumors refractory or resistant to octreotide
LAR: results from a phase II study. Endocrine-Related Cancer 19 657-666. (doi:10.1530/ERC-11-0367)

Kytola S, Nord B, Elder EE, Carling T, Kjellman M, Cedermark B, Juhlin C, Hoog A, Isola J \& Larsson C 2002 Alterations of the SDHD gene locus in midgut carcinoids, Merkel cell carcinomas, pheochromocytomas, and abdominal paragangliomas. Genes, Chromosomes \& Cancer 34 325-332. (doi:10.1002/gcc.10081)

Lam KY, Lo CY, Fan ST \& Luk JM 2000 Telomerase activity in pancreatic endocrine tumours: a potential marker for malignancy. Molecular Pathology 53 133-136. (doi:10.1136/mp.53.3.133)

Larsson C 2013 Epigenetic aspects on therapy development for gastroenteropancreatic neuroendocrine tumors. Neuroendocrinology 97 19-25. (doi:10.1159/000336087)

Lee M, Waser B, Reubi JC \& Pellegata NS 2012 Secretin receptor promotes the proliferation of endocrine tumor cells via the PI3K/AKT pathway. Molecular Endocrinology 26 1394-1405. (doi:10.1210/me.2012-1055)

Lehmann BD \& Pietenpol JA 2012 Targeting mutant $p 53$ in human tumors. Journal of Clinical Oncology 30 3648-3650. (doi:10.1200/JCO.2012. 44.0412)

Leja J, Yu D, Nilsson B, Gedda L, Zieba A, Hakkarainen T, Akerstrom G, Oberg K, Giandomenico V \& Essand M 2011 Oncolytic adenovirus modified with somatostatin motifs for selective infection of neuroendocrine tumor cells. Gene Therapy 18 1052-1062. (doi:10.1038/ gt.2011.54)

Liu L, Broaddus RR, Yao JC, Xie S, White JA, Wu TT, Hamilton SR \& Rashid A 2005 Epigenetic alterations in neuroendocrine tumors: methylation of RAS-association domain family 1 , isoform $A$ and $p 16$ genes are associated with metastasis. Modern Pathology 18 1632-1640. (doi:10.1038/modpathol.3800490)

Lubensky IA \& Zhuang Z 2007 Molecular genetic events in gastrointestinal and pancreatic neuroendocrine tumors. Endocrine Pathology 18 156-162. (doi:10.1007/s12022-007-9007-x)

MacKenzie MJ, Ernst S, Johnson C \& Winquist E 2012 A phase I study of temsirolimus and metformin in advanced solid tumours. Investigational New Drugs 30 647-652. (doi:10.1007/s10637-010-9570-8)

Marinoni I, Kurrer AS, Vassella E, Dettmer M, Rudolph T, Banz V, Hunger F, Pasquinelli S, Speel EJ \& Perren A 2014 Loss of DAXX and ATRX are associated with chromosome instability and reduced survival of patients with pancreatic neuroendocrine tumors. Gastroenterology 146 453-60.e5. (doi:10.1053/j.gastro.2013.10.020)

Marion-Audibert AM, Barel C, Gouysse G, Dumortier J, Pilleul F, Pourreyron C, Hervieu V, Poncet G, Lombard-Bohas C, Chayvialle JA et al. 2003 Low microvessel density is an unfavorable histoprognostic factor in pancreatic endocrine tumors. Gastroenterology 125 1094-1104. (doi:10.1016/S0016-5085(03)01198-3)

von Marschall Z, Scholz A, Cramer T, Schafer G, Schirner M, Oberg K, Wiedenmann B, Hocker M \& Rosewicz S 2003 Effects of interferon $\alpha$ on vascular endothelial growth factor gene transcription and tumor angiogenesis. Journal of the National Cancer Institute 95 437-448. (doi:10.1093/jnci/95.6.437)

Martinsen TC, Kawase S, Hakanson R, Torp SH, Fossmark R, Qvigstad G, Sandvik AK \& Waldum HL 2003 Spontaneous ECL cell carcinomas in cotton rats: natural course and prevention by a gastrin receptor antagonist. Carcinogenesis 24 1887-1896. (doi:10.1093/carcin/bgg156)

Mei M, Deng D, Liu TH, Sang XT, Lu X, Xiang HD, Zhou J, Wu H, Yang Y, Chen J et al. 2009 Clinical implications of microsatellite instability and MLH1 gene inactivation in sporadic insulinomas. Journal of Clinical Endocrinology and Metabolism 94 3448-3457. (doi:10.1210/ jc.2009-0173)

Moyana TN \& Satkunam N 1992 A comparative immunohistochemical study of jejunoileal and appendiceal carcinoids. Implications for histogenesis and pathogenesis. Cancer 70 1081-1088. (doi:10.1002/10970142(19920901)70:5 < 1081::AID-CNCR2820700512>3.0.CO;2-9)

Nishio Y, Nakanishi K, Ozeki Y, Jiang SX, Kameya T, Hebisawa A, Mukai M, Travis WD, Franks TJ \& Kawai T 2007 Telomere length, telomerase activity, and expressions of human telomerase mRNA component 
(hTERC) and human telomerase reverse transcriptase (hTERT) mRNA in pulmonary neuroendocrine tumors. Japanese Journal of Clinical Oncology 37 16-22. (doi:10.1093/jico/hyl118)

Oberg K 1992 The action of interferon $\alpha$ on human carcinoid tumours. Seminars in Cancer Biology 3 35-41.

Oberg K, Funa K \& Alm G 1983 Effects of leukocyte interferon on clinical symptoms and hormone levels in patients with mid-gut carcinoid tumors and carcinoid syndrome. New England Journal of Medicine 309 129-133. (doi:10.1056/NEJM198307213090301)

Orlando C \& Gelmini S 2001 Telomerase in endocrine and endocrinedependent tumors. Journal of Steroid Biochemistry and Molecular Biology 78 201-214. (doi:10.1016/S0960-0760(01)00101-7)

O'Toole D, Saveanu A, Couvelard A, Gunz G, Enjalbert A, Jaquet P, Ruszniewski P \& Barlier A 2006 The analysis of quantitative expression of somatostatin and dopamine receptors in gastro-entero-pancreatic tumours opens new therapeutic strategies. European Journal of Endocrinology 155 849-857. (doi:10.1530/eje.1.02307)

Pavel M 2013 Translation of molecular pathways into clinical trials of neuroendocrine tumors. Neuroendocrinology 97 99-112. (doi:10.1159/ 000336089)

Pavel ME, Hassler G, Baum U, Hahn EG, Lohmann T \& Schuppan D 2005 Circulating levels of angiogenic cytokines can predict tumour progression and prognosis in neuroendocrine carcinomas. Clinical Endocrinology 62 434-443. (doi:10.1111/j.1365-2265.2005.02238.x)

Pavel ME, Hainsworth JD, Baudin E, Peeters M, Horsch D, Winkler RE, Klimovsky J, Lebwohl D, Jehl V, Wolin EM et al. 2011 Everolimus plus octreotide long-acting repeatable for the treatment of advanced neuroendocrine tumours associated with carcinoid syndrome (RADIANT-2): a randomised, placebo-controlled, phase 3 study. Lancet 378 2005-2012. (doi:10.1016/S0140-6736(11)61742-X)

Pietras K \& Hanahan D 2005 A multitargeted, metronomic, and maximumtolerated dose "chemo-switch" regimen is antiangiogenic, producing objective responses and survival benefit in a mouse model of cancer. Journal of Clinical Oncology 23 939-952. (doi:10.1200/JCO.2005.07.093)

Pinato DJ, Tan TM, Toussi ST, Ramachandran R, Martin N, Meeran K, Ngo N, Dina R \& Sharma R 2014 An expression signature of the angiogenic response in gastrointestinal neuroendocrine tumours: correlation with tumour phenotype and survival outcomes. British Journal of Cancer 110 115-122. (doi:10.1038/bjc.2013.682)

Rahman MM, Qian ZR, Wang EL, Yoshimoto K, Nakasono M, Sultana R, Yoshida T, Hayashi T, Haba R, Ishida M et al. 2010 DNA methyltransferases $1,3 \mathrm{a}$, and $3 \mathrm{~b}$ overexpression and clinical significance in gastroenteropancreatic neuroendocrine tumors. Human Pathology $\mathbf{4 1}$ 1069-1078. (doi:10.1016/j.humpath.2010.01.011)

Ramage JK, Ahmed A, Ardill J, Bax N, Breen DJ, Caplin ME, Corrie P, Davar J, Davies AH, Lewington V et al. 2012 Guidelines for the management of gastroenteropancreatic neuroendocrine (including carcinoid) tumours (NETs). Gut 61 6-32. (doi:10.1136/gutjnl-2011-300831)

Raymond E, Dahan L, Raoul JL, Bang YJ, Borbath I, Lombard-Bohas C, Valle J, Metrakos P, Smith D, Vinik A et al. 2011 Sunitinib malate for the treatment of pancreatic neuroendocrine tumors. New England Journal of Medicine 364 501-513. (doi:10.1056/NEJMoa1003825)

Rindi G \& Bordi C 2005 Endocrine tumours of the gastrointestinal tract: aetiology, molecular pathogenesis and genetics. Best Practice \& Research. Clinical Gastroenterology 19 519-534. (doi:10.1016/j.bpg.2005. 03.005)

Rinke A, Muller HH, Schade-Brittinger C, Klose KJ, Barth P, Wied M, Mayer C, Aminossadati B, Pape UF, Blaker M et al. 2009 Placebocontrolled, double-blind, prospective, randomized study on the effect of octreotide LAR in the control of tumor growth in patients with metastatic neuroendocrine midgut tumors: a report from the PROMID Study Group. Journal of Clinical Oncology 27 4656-4663. (doi:10.1200/ JCO.2009.22.8510)

Robertson KD 2005 DNA methylation and human disease. Nature Reviews. Genetics 6 597-610. (doi:10.1038/nrg1655)
Ruden M \& Puri N 2013 Novel anticancer therapeutics targeting telomerase. Cancer Treatment Reviews 39 444-456. (doi:10.1016/j.ctrv. 2012.06.007)

Ryschich E, Autschbach F, Eisold S, Klar E, Buchler MW \& Schmidt J 2003 Expression of HLA class I/II antigens and T cell immune response in human neuroendocrine tumors of the pancreas. Tissue Antigens $\mathbf{6 2}$ 48-54. (doi:10.1034/j.1399-0039.2003.00075.x)

Sadeghi N, Abbruzzese JL, Yeung SC, Hassan M \& Li D 2012 Metformin use is associated with better survival of diabetic patients with pancreatic cancer. Clinical Cancer Research 18 2905-2912. (doi:10.1158/10780432.CCR-11-2994)

Sanchez C, Escrieut C, Clerc P, Gigoux V, Waser B, Reubi JC \& Fourmy D 2012 Characterization of a novel five-transmembrane domain cholecystokinin-2 receptor splice variant identified in human tumors. Molecular and Cellular Endocrinology 349 170-179. (doi:10.1016/j.mce. 2011.10.010)

Sarbassov DD, Guertin DA, Ali SM \& Sabatini DM 2005 Phosphorylation and regulation of Akt/PKB by the rictor-mTOR complex. Science $\mathbf{3 0 7}$ 1098-1101. (doi:10.1126/science.1106148)

Scoazec JY 2013 Angiogenesis in neuroendocrine tumors: therapeutic applications. Neuroendocrinology 97 45-56. (doi:10.1159/000338371)

Scott MG, Benmerah A, Muntaner O \& Marullo S 2002 Recruitment of activated $\mathrm{G}$ protein-coupled receptors to pre-existing clathrin-coated pits in living cells. Journal of Biological Chemistry 277 3552-3559. (doi:10.1074/jbc.M106586200)

Sennino B, Ishiguro-Oonuma T, Wei Y, Naylor RM, Williamson CW, Bhagwandin V, Tabruyn SP, You WK, Chapman HA, Christensen JG et al. 2012 Suppression of tumor invasion and metastasis by concurrent inhibition of c-Met and VEGF signaling in pancreatic neuroendocrine tumors. Cancer Discovery 2 270-287. (doi:10.1158/2159-8290.CD11-0240)

Shay JW, Reddel RR \& Wright WE 2012 Cancer. Cancer and telomeres - an ALTernative to telomerase. Science 336 1388-1390. (doi:10.1126/ science.1222394)

Sherman SP, Li CY \& Carney JA 1979 Microproliferation of enterochromaffin cells and the origin of carcinoid tumors of the ileum: a light microscopic and immunocytochemical study. Archives of Pathology \& Laboratory Medicine 103 639-641.

Solcia E, Bordi C, Creutzfeldt W, Dayal Y, Dayan AD, Falkmer S, Grimelius L \& Havu N 1988 Histopathological classification of nonantral gastric endocrine growths in man. Digestion 41 185-200. (doi:10.1159/ 000199786)

Srirajaskanthan R, Dancey G, Hackshaw A, Luong T, Caplin ME \& Meyer T 2009 Circulating angiopoietin-2 is elevated in patients with neuroendocrine tumours and correlates with disease burden and prognosis. Endocrine-Related Cancer 16 967-976. (doi:10.1677/ERC-09-0089)

Strosberg J \& Kvols L 2010 Antiproliferative effect of somatostatin analogs in gastroenteropancreatic neuroendocrine tumors. World Journal of Gastroenterology 16 2963-2970. (doi:10.3748/wjg.v16.i24.2963)

Svejda B, Kidd M, Giovinazzo F, Eltawil K, Gustafsson BI, Pfragner R \& Modlin IM 2010 The 5- $\mathrm{HT}_{2 \mathrm{~B}}$ receptor plays a key regulatory role in both neuroendocrine tumor cell proliferation and the modulation of the fibroblast component of the neoplastic microenvironment. Cancer 116 2902-2912. (doi:10.1002/cncr.25049)

Tamburini J, Chapuis N, Bardet V, Park S, Sujobert P, Willems L, Ifrah N, Dreyfus F, Mayeux P, Lacombe C et al. 2008 Mammalian target of rapamycin (mTOR) inhibition activates phosphatidylinositol 3-kinase/Akt by up-regulating insulin-like growth factor-1 receptor signaling in acute myeloid leukemia: rationale for therapeutic inhibition of both pathways. Blood 111 379-382. (doi:10.1182/blood2007-03-080796)

Tang LH, Contractor T, Clausen R, Klimstra DS, Du YC, Allen PJ, Brennan MF, Levine AJ \& Harris CR 2012 Attenuation of the retinoblastoma pathway in pancreatic neuroendocrine tumors due to increased Cdk4/Cdk6. Clinical Cancer Research 8 4612-4620. (doi:10.1158/1078-0432.CCR-11-3264) 
Tawadros T, Alonso F, Jichlinski P, Clarke N, Calandra T, Haefliger JA \& Roger T 2013 Release of macrophage migration inhibitory factor by neuroendocrine-differentiated LNCaP cells sustains the proliferation and survival of prostate cancer cells. Endocrine-Related Cancer 20 137-149. (doi:10.1530/ERC-12-0286)

Terris B, Scoazec JY, Rubbia L, Bregeaud L, Pepper MS, Ruszniewski P, Belghiti J, Flejou J \& Degott C 1998 Expression of vascular endothelial growth factor in digestive neuroendocrine tumours. Histopathology 32 133-138. (doi:10.1046/j.1365-2559.1998.00321.x)

Tonnies H, Toliat MR, Ramel C, Pape UF, Neitzel H, Berger W \& Wiedenmann B 2001 Analysis of sporadic neuroendocrine tumours of the enteropancreatic system by comparative genomic hybridisation. Gut 48 536-541. (doi:10.1136/gut.48.4.536)

Topalian SL, Hodi FS, Brahmer JR, Gettinger SN, Smith DC, McDermott DF, Powderly JD, Carvajal RD, Sosman JA, Atkins MB et al. 2012 Safety, activity, and immune correlates of anti-PD- 1 antibody in cancer. New England Journal of Medicine 366 2443-2454. (doi:10.1056/ NEJMoa1200690)

Varker KA, Campbell J \& Shah MH 2008 Phase II study of thalidomide in patients with metastatic carcinoid and islet cell tumors. Cancer Chemotherapy and Pharmacology 61 661-668. (doi:10.1007/s00280-0070521-9)

Vikman S, Sommaggio R, De La Torre M, Oberg K, Essand M, Giandomenico V, Loskog A \& Totterman TH 2009 Midgut carcinoid patients display increased numbers of regulatory $\mathrm{T}$ cells in peripheral blood with infiltration into tumor tissue. Acta Oncologica 48 391-400. (doi:10.1080/02841860802438495)

Waser B, Cescato R, Liu Q, Kao YJ, Korner M, Christ E, Schonbrunn A \& Reubi JC 2012a Phosphorylation of sst2 receptors in neuroendocrine tumors after octreotide treatment of patients. American Journal of Pathology 180 1942-1949. (doi:10.1016/j.ajpath.2012.01.041)

Waser B, Rehmann R, Sanchez C, Fourmy D \& Reubi JC 2012b Glucosedependent insulinotropic polypeptide receptors in most gastroenteropancreatic and bronchial neuroendocrine tumors. Journal of Clinical Endocrinology and Metabolism 97 482-488. (doi:10.1210/jc.2011-2454)

Wild D, Christ E, Caplin ME, Kurzawinski TR, Forrer F, Brandle M, Seufert J, Weber WA, Bomanji J, Perren A et al. 2011 Glucagon-like peptide-1 versus somatostatin receptor targeting reveals 2 distinct forms of malignant insulinomas. Journal of Nuclear Medicine 52 1073-1078. (doi:10.2967/jnumed.110.085142)

Wolin EM, Hu K, Hughes G, Bouillaud E, Giannone V \& Resendiz KH 2013 Safety, tolerability, pharmacokinetics, and pharmacodynamics of a long-acting release (LAR) formulation of pasireotide (SOM230) in patients with gastroenteropancreatic neuroendocrine tumors: results from a randomized, multicenter, open-label, phase I study. Cancer Chemotherapy and Pharmacology 72 387-395. (doi:10.1007/s00280013-2202-1)

Yachida S, Vakiani E, White CM, Zhong Y, Saunders T, Morgan R, de Wilde RF, Maitra A, Hicks J, Demarzo AM et al. 2012 Small cell and large cell neuroendocrine carcinomas of the pancreas are genetically similar and distinct from well-differentiated pancreatic neuroendocrine tumors. American Journal of Surgical Pathology 36 173-184. (doi:10.1097/ PAS.0b013e3182417d36)

Yao JC, Hassan M, Phan A, Dagohoy C, Leary C, Mares JE, Abdalla EK, Fleming JB, Vauthey JN, Rashid A et al. 2008a One hundred years after "carcinoid": epidemiology of and prognostic factors for neuroendocrine tumors in 35,825 cases in the United States. Journal of Clinical Oncology 26 3063-3072. (doi:10.1200/JCO.2007.15.4377)

Yao JC, Phan A, Hoff PM, Chen HX, Charnsangavej C, Yeung SC, Hess K, Ng C, Abbruzzese JL \& Ajani JA 2008b Targeting vascular endothelial growth factor in advanced carcinoid tumor: a random assignment phase II study of depot octreotide with bevacizumab and pegylated interferon $\alpha$-2b. Journal of Clinical Oncology 26 1316-1323. (doi:10.1200/JCO.2007.13.6374)

Yao JC, Shah MH, Ito T, Bohas CL, Wolin EM, Van Cutsem E, Hobday TJ, Okusaka T, Capdevila J, de Vries EG et al. 2011 Everolimus for advanced pancreatic neuroendocrine tumors. New England Journal of Medicine 364 514-523. (doi:10.1056/NEJMoa1009290)

Yokoyama A, Wang Z, Wysocka J, Sanyal M, Aufiero DJ, Kitabayashi I, Herr W \& Cleary ML 2004 Leukemia proto-oncoprotein MLL forms a SET1-like histone methyltransferase complex with menin to regulate Hox gene expression. Molecular and Cellular Biology 24 5639-5649. (doi:10.1128/MCB.24.13.5639-5649.2004)

Zaffaroni N, Villa R, Pastorino U, Cirincione R, Incarbone M, Alloisio M, Curto M, Pilotti S \& Daidone MG 2005 Lack of telomerase activity in lung carcinoids is dependent on human telomerase reverse transcriptase transcription and alternative splicing and is associated with long telomeres. Clinical Cancer Research 11 2832-2839. (doi:10.1158/ 1078-0432.CCR-04-1293)

Zhang HY, Rumilla KM, Jin L, Nakamura N, Stilling GA, Ruebel KH, Hobday TJ, Erlichman C, Erickson LA \& Lloyd RV 2006 Association of DNA methylation and epigenetic inactivation of RASSF1A and $\beta$-catenin with metastasis in small bowel carcinoid tumors. Endocrine $\mathbf{3 0}$ 299-306. (doi:10.1007/s12020-006-0008-1)

Zhang J, Jia Z, Li Q, Wang L, Rashid A, Zhu Z, Evans DB, Vauthey JN, Xie K \& Yao JC 2007 Elevated expression of vascular endothelial growth factor correlates with increased angiogenesis and decreased progression-free survival among patients with low-grade neuroendocrine tumors. Cancer 109 1478-1486. (doi:10.1002/cncr.22554)

Zhang Q, Yang M, Shen J, Gerhold LM, Hoffman RM \& Xing HR 2010 The role of the intravascular microenvironment in spontaneous metastasis development. International Journal of Cancer 126 2534-2541. (doi:10.1002/ijc.24739)

Zitzmann K, Ruden J, Brand S, Goke B, Lichtl J, Spottl G \& Auernhammer CJ 2010 Compensatory activation of Akt in response to mTOR and Raf inhibitors - a rationale for dual-targeted therapy approaches in neuroendocrine tumor disease. Cancer Letters 295 100-109. (doi:10.1016/j.canlet.2010.02.018)

Zou W 2006 Regulatory T cells, tumour immunity and immunotherapy. Nature Reviews. Immunology 6 295-307. (doi:10.1038/nri1806)

Received in final form 14 August 2014

Accepted 20 August 2014 http://erc.endocrinology-journals.org DOI: 10.1530/ERC-14-0106
(C) 2014 Society for Endocrinology Printed in Great Britain
Published by Bioscientifica Ltd. 